\title{
Enhancement of Lipid Metabolism and Hepatic Stability in Fat-Induced Obese Mice by Fermented Cucurbita moschata Extract
}

\author{
Md. Akil Hossain (iD, ${ }^{1,2}$ Seung-Jin Lee, ${ }^{1}$ Na-Hye Park, ${ }^{1}$ \\ Biruk Tesfaye Birhanu, ${ }^{1}$ Abraham Fikru Mechesso, ${ }^{1}$ Ji-Yong Park, ${ }^{1}$ Eun-Jin Park, ${ }^{3}$ \\ Sam-Pin Lee $\mathbb{D}^{1},{ }^{3}$ Sun-Joo Youn, ${ }^{4}$ and Seung-Chun Park ${ }^{1}{ }^{1}$ \\ ${ }^{1}$ College of Veterinary Medicine, Kyungpook National University, Daegu 702-701, Republic of Korea \\ ${ }^{2}$ Veterinary Drugs \& Biologics Division, Animal and Plant Quarantine Agency (APQA), 177 Hyeoksin 8-ro, \\ Gimcheon-si, Gyeongsangbuk-do 39660, Republic of Korea \\ ${ }^{3}$ Department of Food Science and Technology, Keimyung University, Daegu 704-701, Republic of Korea \\ ${ }^{4}$ The Aramfarm Co., Ltd, Gyeongsan 38497, Republic of Korea \\ Correspondence should be addressed to Sam-Pin Lee; splee@kmu.ac.kr and Seung-Chun Park; parksch@knu.ac.kr
}

Received 28 February 2017; Accepted 17 December 2017; Published 13 March 2018

Academic Editor: Srinivas Nammi

Copyright (c) $2018 \mathrm{Md}$. Akil Hossain et al. This is an open access article distributed under the Creative Commons Attribution License, which permits unrestricted use, distribution, and reproduction in any medium, provided the original work is properly cited.

\begin{abstract}
The aim of this study was to evaluate the potentials of fermented Cucurbita moschata extract (FCME) in the treatment of obesity and nonalcoholic fatty liver disease (NAFLD). Five-week-old male C57BL/6 mice were assigned to 6 groups and treated for 8 weeks by feeding the normal diet (ND) and high fat diet (HFD) with and without FCME. Changes in body weight gain and consumption of feed and water were recorded. Major organs, adipose tissues, and blood samples were collected after the experimental period. The serum lipid profile, histological features of liver and adipose tissues, and mRNA expression of different adipogenic/lipogenic genes from liver tissue were evaluated. The supplementation of FCME in HFD significantly prevented HFD-induced increment of bodyweight. The adipose tissue mass, liver enzymes, and plasma lipids were also reduced significantly $(p<0.05)$ by the consumption of FCME. The mRNA expressions of adipogenic/lipogenic genes (PPAR $\gamma, \mathrm{C} / \mathrm{EBP} \alpha, \mathrm{C} / \mathrm{EBP}_{\beta}, \mathrm{C} / \mathrm{EBP} \gamma$, and SREBP$1 C)$ in FCME-treated obese mice were considerably $(p<0.05)$ suppressed. FCME showed its antiobesity potential by suppressing the body weight gain and by modulating the plasma lipids and liver enzymes through the regulation of adipogenic/lipogenic transcriptional factors. Fermented Cucurbita moschata could be an opportunistic agent in controlling obesity and fatty liver changes.
\end{abstract}

\section{Introduction}

Obesity is a major health concern of the 21st century, serving as a risk factor for various diseases, including diabetes, coronary artery disease, arthritis, and hypertension [1]. Obesity is associated with a spectrum of liver abnormalities, known as nonalcoholic fatty liver disease (NAFLD). NAFLD has become an important public health problem due to its high pervasiveness, association with serious cardiometabolic abnormalities, and potential progression to severe liver diseases [2]. Currently, NAFLD treatments include exercise, balanced diet, and medications like metformin, fibrates, statins, orlistat, lorcaserin, and sibutramine. Although, these drugs are reported for several adverse effects or contraindications, there is still no consensus on the most effective drug therapy [3]. Therefore, new candidates with high efficiency and no or little side effects are immediately required to treat NAFLD and obesity. In the last decade, nutraceuticals and functional foods have attracted great scientific interest, with a number of clinical trials and animal studies addressing their potential roles in blood lipid control [4]. The beneficial hypocholesterolemic and/or antioxidant effects of two plant-derived substances, 
$\mathrm{N}$-acetylcysteine (NAC) and sesame oil, have been reported previously [5]. One of the opportunistic natural agents, namely, pumpkin, has received substantial considerations recently because of the nutritional and health-enhancing value of the seeds as well as the polysaccharides from the fruit [6].

Pumpkin (Cucurbita moschata) is rich in polysaccharides, vitamins, mineral salts, carotene, and other substances beneficial to health [10]. Pumpkin seeds were used by Native Americans to treat intestinal infections, which finally led the United States Pharmacopoeia to list pumpkin seeds as an official medicine for parasite elimination from 1863 to 1936. Preliminary investigations showed that a pumpkin-rich diet could reduce blood glucose, and the active polysaccharides from the pumpkin fruit could evidently increase the serum insulin levels, reduce the levels of blood glucose, improve glucose tolerance, and hence be developed as new antidiabetic agent [10].

Recent evidence suggests that high serum cholesterol concentration can be treated using a different factor, the gut microbiota. Lactobacilli are one of the vital health-enhancing microbiota which is frequently found as probiotics in cultured milks, infant foods, and different pharmaceutical preparations. One beneficial effect that has been suggested to result from human consumption of probiotic lactic acid bacteria (LAB) is a reduction in serum cholesterol levels [11]. One of the probiotic LAB, Lactobacillus plantarum, is also reported for having hypocholesterolemic effects in different studies [12]. It was demonstrated in previous study that Bacillus subtilis has hypoglycemic and antilipidemic activities [13]. Several studies have reported that probiotic-fermented food shows hypolipidemic effects [14]. Furthermore, fermentation significantly improves the functional properties of pumpkin products [10].

Thus, the current study was designed to evaluate the protective effect of fermented Cucurbita moschata extract against obesity and NAFLD in a high fat diet-induced obese mice model and to reveal the possible mechanism underlying to this assumed effect. Moreover, the safety profile of this fermented extract was assessed in vivo and the functional compounds were identified. To our knowledge, this is the first report of using fermented Cucurbita moschata extract to control the obesity and NAFLD.

\section{Methods}

2.1. Chemicals and Reagents. Garcinia extract containing $\geq$ $600 \mathrm{mg} / \mathrm{g}$ hydroxycitric acid (HCA) was obtained from Unicorn Natural Products Private Limited (Hyderabad, India). HPLC grade formic acid and acetonitrile were purchased from Honeywell Burdick \& Jackson (Ulsan, South Korea).

2.2. Fermentation of Cucurbita moschata. Peeled Cucurbita moschata (pumpkin) was purchased from Aram farm Co. (Yeongcheon, South Korea) and then homogenized with two volumes of water. The pumpkin paste was fortified with 3\% glucose and $1.5 \%$ monosodium glutamate to prepare $2.5 \mathrm{~L}$ culture medium, followed by sterilization at $121^{\circ} \mathrm{C}$ for $15 \mathrm{~min}$. Bacillus subtilis HA was cultured in nutrient broth for 1 day. Cells were harvested by centrifuge at $22,500 \times \mathrm{g}$ for $15 \mathrm{~min}$ and then washed with sterilized saline solution. The cell suspension of 10 times concentration was prepared to be inoculated with $1 \%$ level. The submerged culture was performed with $5 \mathrm{~L}$ jar fermentor (Fermentex Co. Ltd., Cheongwon, South Korea) in the condition of $450 \mathrm{rpm}$ and air supply of 2.5 $3 \mathrm{~L} / \mathrm{min}$ at $42^{\circ} \mathrm{C}$ for 2 days. For the second fermentation using Lactobacillus plantarum EJ2014, starter culture grown in MRS broth for 1 day at $30^{\circ} \mathrm{C}$ was inoculated in the first fermented culture broth with $1 \%$ level. The mixed culture was cultivated by slightly shaking with $100 \mathrm{rpm}$ at $30^{\circ} \mathrm{C}$ for 3 days. Final culture broth obtained by mixed fermentation using B. subtilis and L. plantarum was freeze-dried using a freeze dryer (Ilshinbiobase Co. Ltd., Docheon, South Korea) and preserved in $4^{\circ} \mathrm{C}$ refrigerator.

2.3. Animal Experimental Design. Five-week-old male C57BL/6 mice of 19-21 g were purchased from Orient Co. Seoul, South Korea (Charles River Technology). The animals were maintained at $20-25^{\circ} \mathrm{C}$ temperature, $55 \pm 10 \%$ relative humidity, and $12 \mathrm{~h}$ light/dark cycle under specific-pathogenfree condition. Feed and water were given ad libitum. After 1 week of acclimatization, the mice were randomly assigned to 6 groups (10/group) as follows: control (normal diet, AIN76A \#100000, Dyets Inc., Bethlehem, PA, USA), high fat diet (HFD) containing $40 \%$ beef tallow modified AIN-76A purified rodent diet (\#101556, Dyets Inc., Bethlehem, PA, USA), HFD with $0.3 \%$ HCA (in Garcinia extract), and HFD with $0.1 \%, 0.3 \%, 0.5 \%$ fermented Cucurbita moschata extract (FCME). HFD was fed for 8 weeks to induce the hyperlipidemia and obesity in mice. The composition of ND and HFD are presented in Supplementary Table 1. The animal experimental protocols were approved by the Institutional Animal Care and Use Committee of Kyungpook National University (approval number KNU 2011-1). The changes in body weight, feed, and water intake were recorded routinely. At the end of the experiment, blood was collected from the hearts of the mice under anesthesia. After euthanasia, kidney, liver, spleen, and the adipose tissues (subcutaneous, mesenteric, perirenal, and epididymal) were immediately collected, weighted, and preserved.

2.4. Biochemical Analysis of Serum. After overnight fasting, mice were anesthetized with diethyl-ether, and blood samples were collected from the hearts of mice into serum extraction tubes and allowed to coagulate properly. The tubes were centrifuged at $1500 \times \mathrm{g}$ for $10 \mathrm{~min}$ at $4^{\circ} \mathrm{C}$, and the serum was collected immediately. Biochemical examinations were performed for serum concentrations of total cholesterol (TC), high density lipoprotein (HDL), triglycerides (TG), and free fatty acid. Low density lipoprotein (LDL) was calculated by subtracting HDL from TC, and the atherogenic index (AI) was calculated as TC - HDL/HDL. These two formulas for calculating the LDL and AI are stated in many articles including in the article of Reza et al. [15]. Aspartate aminotransferase (AST) and alanine aminotransferase (ALT) were measured to determine the liver function.

The endocrine peptides such as ghrelin, leptin, insulin, and GIP (glucose-dependent insulin-releasing polypeptide) were also measured. All biochemical examinations were 
conducted by using commercially available ELISA kits. The employed ELISA kits of ALT, AST, free fatty acid, HDL, and TC were from Sigma-Aldrich Co. LLC. (St. Louis, MO 63103, USA); TG and insulin from abcam (Cambridge CB4 OF4, United Kingdom); ghrelin and leptin from EMD Millipore Corporation (Missouri 63304, USA); and GIP from Cusabio (Hubei 430206, China).

2.5. Histopathological Study of Liver Tissue. Liver tissues were fixed in $10 \%$ buffered formaldehyde. Tissue sections $(5 \mu \mathrm{m})$ were stained with Ehrlich's hematoxylin and eosin (H\&E) and examined for the severity of hepatic steatosis as described previously [15].

2.6. Determination of Adipocyte Size. Adipocyte sizes in mice's adipose tissue were measured in paraffin-embedded tissue. Briefly, samples of mesenteric, subcutaneous, epididymal, and perirenal adipose tissue were fixed in $10 \%$ formalin and then embedded in paraffin. Tissue sections were cut into $5 \mu \mathrm{m}$ with a microtome (Leica, Germany) and mounted on Superfrost/Plus Microscope Slides. After being air-dried, they were stained with Ehrlich's hematoxylin and eosin and photographed at 100x magnification. At least two fields per slice and six slices per fat mass were analyzed for determining adipocyte size. The same region of the fat pad was used for all animals to minimize cell size variation due to differences in anatomical location.

2.7. Extraction of RNA from Liver Tissue. Frozen liver tissue was cut into slices and about $80 \mathrm{mg}$ of the tissue was immediately transferred to an eppendorf tube. One milliliter of Trizol reagent was added and the tissue was homogenized periodically with IKA T10 basic Homogenizer (Seoul, South Korea) by keeping the tube on ice. RNA extraction was performed according to the protocol for the Trizol reagent. The resulting solution was diluted 100 -fold, purity was confirmed, and RNA concentration $(\mu \mathrm{g} / \mathrm{mL})$ was calculated by measuring absorbance at 260 and $280 \mathrm{~nm}$ using a U2800 spectrophotometer (Hitachi High Technologies, Tokyo, Japan).

2.8. Real-Time Quantitative PCR. cDNA was synthesized from $100 \mathrm{ng}$ of RNA by using RNA to cDNA EcoDry Premix (Oligo dT) (Clontech Laboratories, Inc., Seoul 153-779, South Korea) according to the supplied protocol. The expression of target genes was detected by performing real-time PCR with the primers listed in Supplementary Table 2. To each PCR tube (TLS0851, Bio-Rad Laboratories Inc., Herts HP2 7DX, United Kingdom), $12.5 \mu$ L of SYBR Select Master Mix for CFX (Applied Biosystems, Foster City, CA 94404, USA), $1 \mu \mathrm{L}$ of forward primer $(10 \mathrm{pmol}), 1 \mu \mathrm{L}$ of reverse primer $(10 \mathrm{pmol})$ of target gene, $9.5 \mu \mathrm{L}$ of RNase-free water, and $1 \mu \mathrm{L}$ of cDNA were added, mixed by pipetting, and spined down. The realtime PCR reaction was accomplished in CFX96 Touch $^{\mathrm{TM}}$ RealTime PCR Detection System (Bio-Rad Laboratories Inc., Irvine, CA 92618, USA) with 35 cycles of denaturation at $94^{\circ} \mathrm{C}$ for $30 \mathrm{~s}$, annealing at $58^{\circ} \mathrm{C}$ for $45 \mathrm{~s}$, and elongation at $72^{\circ} \mathrm{C}$ for $30 \mathrm{~s}$. mRNA expressions were normalized using $\beta$-actin. All
mRNA expressions were expressed in relation to the average expression of the ND group (100\%).

2.9. Acute Oral Toxicity. Ten female Sprague-Dawley rats that were 8 weeks old were obtained from Orient Bio Inc. (Gyeonggi-do, South Korea). Animals were maintained in standard conditions as stated in Animal Experimental Design. The acute toxicity study was performed by slightly modifying a previously reported method [16]. Rats were randomly assigned to control and test groups (5 rats in each group). A single dose $(2000 \mathrm{mg} / \mathrm{kg}$ of body weight) of FCME was administered intragastrically according to OECD test guideline 423. The animals were observed for abnormal signs and symptoms for first $12 \mathrm{~h}$ after the administration of FCME. They were also observed daily for 2 weeks. The changes in body weight, feed, and water intake were measured twice a week for 14 days. At the end of the experiment, animals were sacrificed, and major organs were collected and inspected for gross lesions.

2.10. Compound Profile Analysis of FCME. LC-MS analysis of FCME was accomplished by Agilent 1100 series LC system (Agilent Technologies, Santa Clara, CA) equipped with an Agilent 1946B mass selective detector (MSD) (Agilent Technologies, Santa Clara, CA). A Pursuit XRs C18 (2.0 mm × $150 \mathrm{~mm}, 3 \mu \mathrm{m})$ column was utilized at a flow rate of $0.2 \mathrm{~mL} / \mathrm{min}$ at $40^{\circ} \mathrm{C}$. The mobile phase consists of $\mathrm{A}(0.1 \%$ formic acid in water) and B ( $0.1 \%$ formic acid in acetonitrile). The run time for each sample was $60 \mathrm{~min}$, and the mobile phase started with $95 \%$ " $A$ " and $5 \%$ "B" in the first $2 \mathrm{~min}$; then " $A$ " was decreased gradually to $0 \%$ until the 50 th min and held for an additional $5 \mathrm{~min}$. Thereafter, the proportion of " $\mathrm{A}$ " was increased to $95 \%$ within $5 \mathrm{~min}$. The compounds were analyzed in selected ion monitoring (SIM) mode.

GC/MS analysis of FCME was performed by Kyungpook National University Center for Scientific Instruments and carried out using a HP 6890 Plus GC gas chromatograph with a (MSD) - HP 5973 MSD mass selective detector (HewlettPackard). Samples were diluted 1:1000 (v:v) with HPLC grade dichloromethane. Aliquots of the sample $(1 \mu \mathrm{L})$ were injected into an HP-5 column. The GC oven temperature was set at $50^{\circ} \mathrm{C}$ for $4 \mathrm{~min}$, increased to $280^{\circ} \mathrm{C}$ at a rate of $4^{\circ} \mathrm{C} / \mathrm{min}$, and held at the final temperature for $2 \mathrm{~min}$. Velocity of the $\mathrm{He}$ carrier gas (99.99\%) was $0.7 \mathrm{~mL} / \mathrm{min}$. Quantitative analysis was performed using the area normalization method.

2.11. Statistical Analysis. Data are presented as mean \pm standard error of three replicate assays. Analysis of variance (ANOVA) and $F$-test were performed and $p$ values of less than 0.05 were considered to be statistically significant.

\section{Results}

3.1. Effect of FCME on Feed and Water Consumption and Body Weight Gain. The body weight of HFD-fed mice increased significantly compared to other groups within the experimental period (Figure 1(a)). Feed intake and water intake were not affected significantly in different groups of animal (Figures 1(b) and 1(c)). The FCME plus HFD-fed 


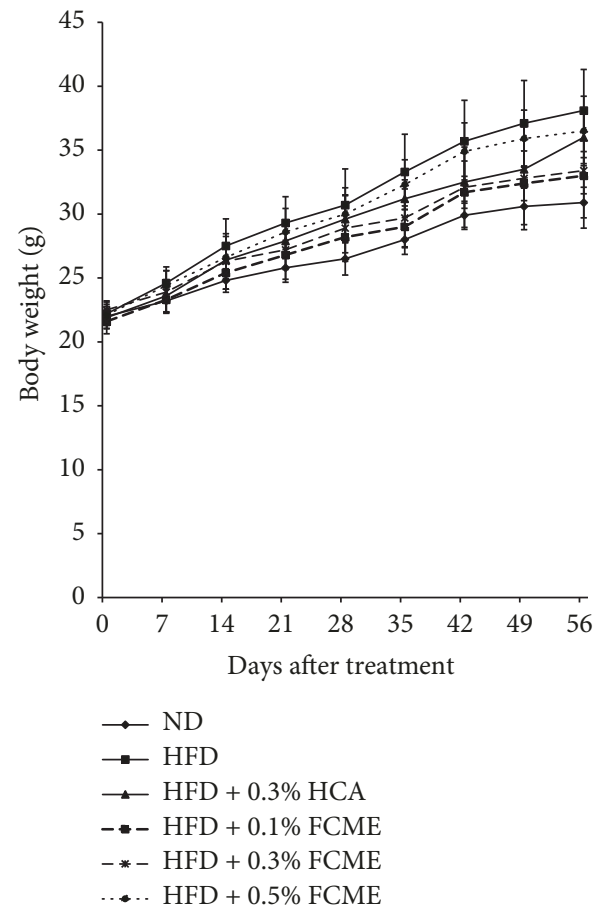

(a)

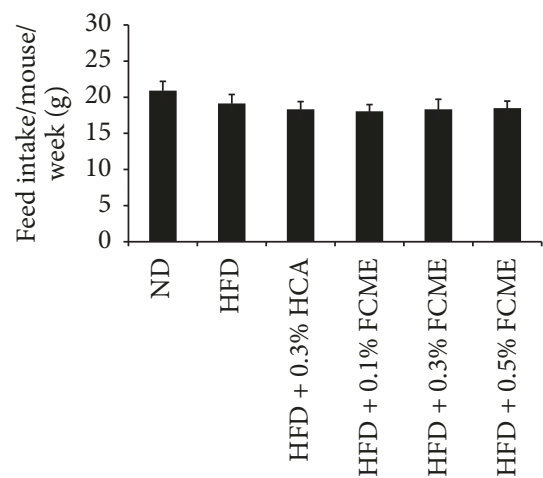

(b)

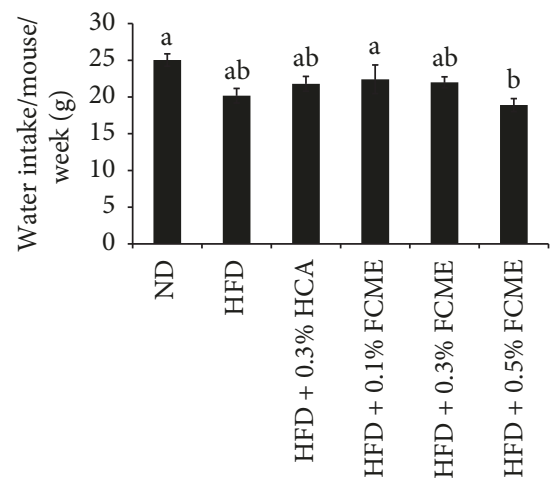

(c)

FiguRE 1: Effect of fermented Cucurbita moschata extract (FCME) on (a) body weight gain, (b) feed intake, and (c) water intake in high fat diet-fed C57BL/10 male mice for 8 weeks. Results are expressed as mean \pm SE of 10 mice in each group. Values not having the same superscript letter are significantly different $(p<0.05)$ by ANOVA.

mice showed a reduced body weight gain better than HCA group. It is demonstrated that there were no significant differences in the weight of kidney and spleen among different groups (Table 1). The weights of liver and adipose tissues (subcutaneous, mesenteric, perirenal, and epididymal) were increased considerably in HFD-fed mice compared to mice of ND group. The weights of liver and adipose tissues were noticeably lowered in $0.1 \%$ and $0.3 \%$ FCME-supplemented HFD-fed mice compared to mice fed only HFD.

3.2. Effect of FCME on Serum Lipids. The impact of FCME on serum lipid profile is presented in Figure 2. Hyperlipidemia was observed in HFD-fed obese mice with elevated serum concentration of LDL, TG, free fatty acid, and TC. Free fatty acid, TC, TG, and LDL concentrations in serum were significantly reduced in FCME-treated groups (0.1-0.5\%) to the levels of ND-fed mice. Accordingly, FCME treatment significantly lowered AI values in HFD-fed obese mice.

\subsection{Effect of FCME on Endocrine Peptides and Liver Function} Enzymes. The impact of FCME on leptin, ghrelin, insulin, and GIP of mice serum are shown in Figure 3. Feeding of HFD increased the leptin level in mice which was markedly reduced with the supplementation of FCME (0.1-0.3\%) in HFD. The levels of insulin and GIP in mice serum were also reduced significantly by feeding FCME-supplemented HFD. The serum concentrations of AST and ALT were pronouncedly high in HFD-fed obese mice (Figure 3). However, the concentrations of AST and ALT were reduced significantly in mice fed with FCME-supplemented HFD. 
TABLE 1: Effect of fermented Cucurbita moschata extract on organs weight.

\begin{tabular}{|c|c|c|c|c|c|c|}
\hline Name of organ & ND & HFD & $\mathrm{HFD}+0.3 \% \mathrm{HCA}$ & $\mathrm{HFD}+0.1 \%$ FCME & $\mathrm{HFD}+0.3 \%$ FCME & $\mathrm{HFD}+0.5 \% \mathrm{FCME}$ \\
\hline Liver (g) & $0.95 \pm 0.05^{\mathrm{b}}$ & $1.16 \pm 0.05^{\mathrm{a}}$ & $1.13 \pm 0.05^{\mathrm{a}}$ & $0.91 \pm 0.04^{\mathrm{b}}$ & $0.94 \pm 0.05^{\mathrm{b}}$ & $1.04 \pm 0.04^{\mathrm{ab}}$ \\
\hline Kidney (Right) (g) & $0.18 \pm 0.01$ & $0.18 \pm 0.01$ & $0.18 \pm 0.01$ & $0.17 \pm 0.01$ & $0.17 \pm 0.01$ & $0.17 \pm 0.01$ \\
\hline Kidney (Left) (g) & $0.17 \pm 0.01^{\mathrm{ab}}$ & $0.18 \pm 0.01^{\mathrm{a}}$ & $0.17 \pm 0.01^{\mathrm{ab}}$ & $0.16 \pm 0.01^{\mathrm{ab}}$ & $0.15 \pm 0.01^{\mathrm{b}}$ & $0.16 \pm 0.01^{\mathrm{ab}}$ \\
\hline Spleen (g) & $0.08 \pm 0.00^{\mathrm{ab}}$ & $0.09 \pm 0.00^{\mathrm{a}}$ & $0.07 \pm 0.01^{\mathrm{ab}}$ & $0.07 \pm 0.00^{\mathrm{b}}$ & $0.07 \pm 0.00^{\mathrm{ab}}$ & $0.07 \pm 0.01^{\mathrm{b}}$ \\
\hline Mesenteric adipose tissue (g) & $0.40 \pm 0.02^{\mathrm{b}}$ & $1.01 \pm 0.11^{\mathrm{a}}$ & $0.80 \pm 0.05^{\mathrm{a}}$ & $0.57 \pm 0.05^{\mathrm{b}}$ & $0.49 \pm 0.08^{\mathrm{b}}$ & $0.81 \pm 0.10^{\mathrm{a}}$ \\
\hline Epididymal adipose tissue (g) & $0.69 \pm 0.06^{\mathrm{c}}$ & $1.86 \pm 0.17^{\mathrm{a}}$ & $1.77 \pm 0.07^{\mathrm{a}}$ & $1.41 \pm 0.11^{\mathrm{b}}$ & $1.01 \pm 0.15^{\mathrm{c}}$ & $1.84 \pm 0.10^{\mathrm{a}}$ \\
\hline Subcutaneous adipose tissue (g) & $0.36 \pm 0.04^{c}$ & $1.08 \pm 0.12^{\mathrm{a}}$ & $0.95 \pm 0.06^{\mathrm{a}}$ & $0.65 \pm 0.06^{\mathrm{b}}$ & $0.46 \pm 0.10^{\mathrm{bc}}$ & $0.91 \pm 0.11^{\mathrm{a}}$ \\
\hline Perirenal adipose tissue ( $\mathrm{g}$ ) & $0.29 \pm 0.03^{c}$ & $1.03 \pm 0.11^{\mathrm{a}}$ & $0.94 \pm 0.05^{\mathrm{a}}$ & $0.57 \pm 0.05^{\mathrm{b}}$ & $0.46 \pm 0.10^{\mathrm{bc}}$ & $0.89 \pm 0.07^{\mathrm{a}}$ \\
\hline Total adipose tissue (g) & $1.74 \pm 0.12^{\mathrm{c}}$ & $4.98 \pm 0.48^{\mathrm{a}}$ & $4.46 \pm 0.20^{\mathrm{a}}$ & $3.20 \pm 0.23^{\mathrm{b}}$ & $2.42 \pm 0.41^{\mathrm{bc}}$ & $4.45 \pm 0.34^{\mathrm{a}}$ \\
\hline
\end{tabular}

ND: normal diet; HFD: high fat diet; HCA: hydroxycitric acid; FCME: fermented Cucurbita moschata extract. Values are presented as mean \pm SE $(n=10)$; values not having the same superscript letter are significantly different $(p<0.05)$ by ANOVA.

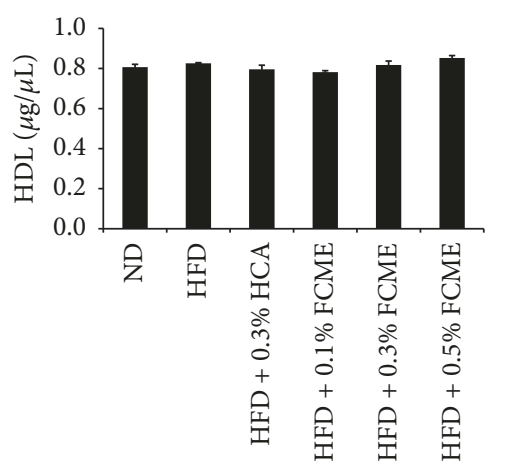

(a)

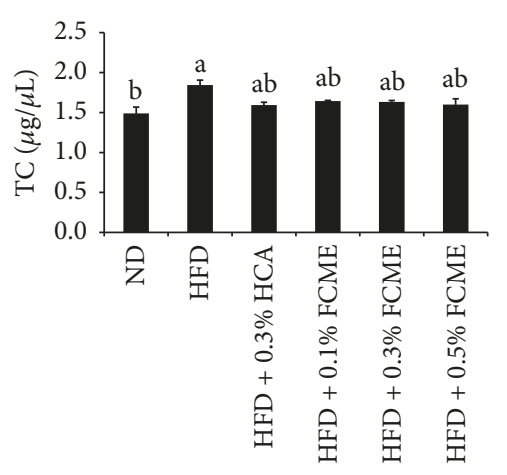

(d)

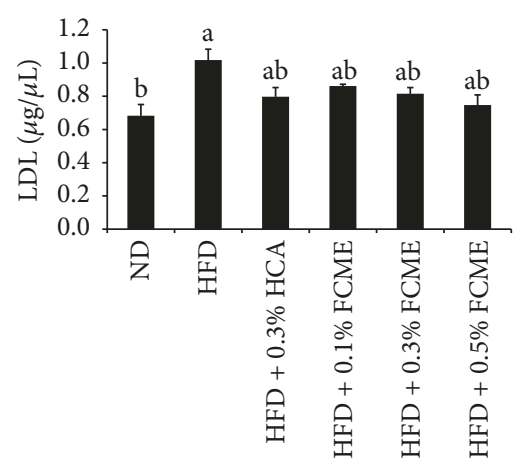

(b)

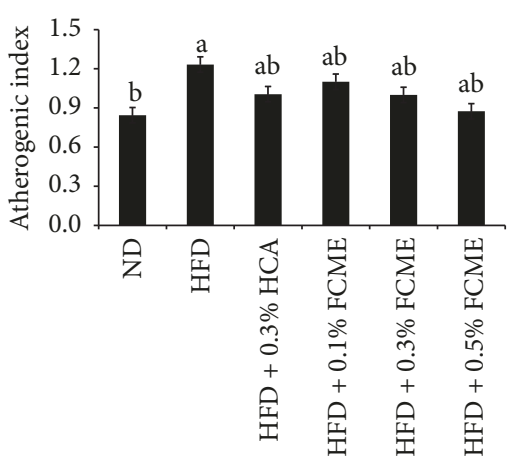

(e)

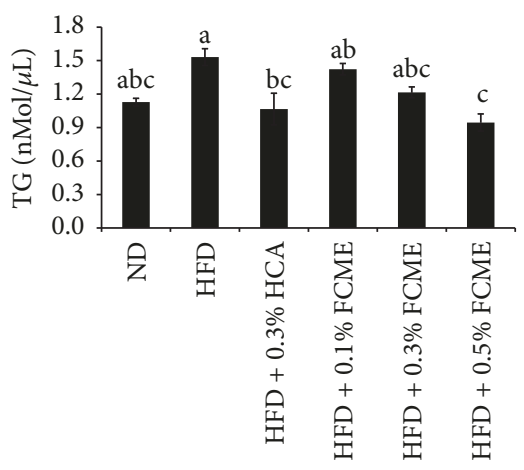

(c)

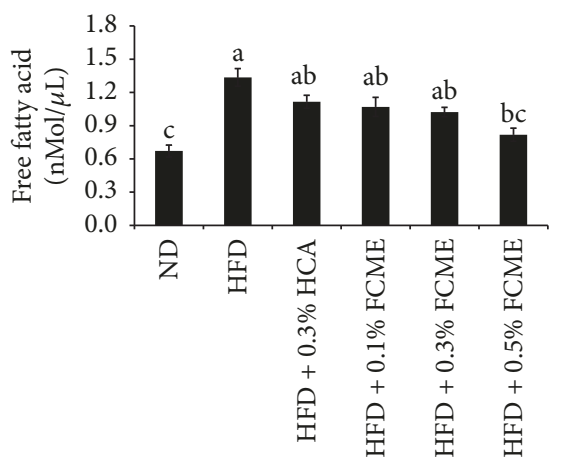

(f)

FIGURE 2: Changes of serum lipids in mice fed with normal diet; and high fat diet with or without $0.1 \%, 0.3 \%$, and $0.5 \%$ of fermented Cucurbita moschata extract (FCME) for 8 weeks. (a) HDL, (b) LDL, (c) TG, (d) TC, (e) AI, and (f) FFA. Different superscript letters are significantly different $(p<0.05)$ by ANOVA.

3.4. Effects of FCME on Hepatic Tissue and Adipocyte. The histopathological changes in liver tissues of mice associated with the feeding of HFD and FCME are summarized in Table 2 and Figure 4. The liver slices of ND-fed mice exhibited normal lobular architecture with well-structured hepatocytes. The feeding of HFD for 8 weeks ominously induced the steatosis, lobular activity, portal inflammation with fat droplets accumulation in hepatic tissues of mice. An increase in the accumulation of fat droplets was observed in the livers of the mice fed with HFD for 8 weeks compared to the ND-fed mice. The feeding of FCME-supplemented HFD to mice showed no or comparatively less accumulation of fat droplets in their hepatic tissues. Further, the addition of FCME in HFD significantly reduced steatosis, ballooning, hepatic inflammation, or lobular activity in mice (Table 2). The architecture and morphology of hepatocytes in FCMEtreated mice were comparable to that observed in ND-fed mice.

The effects of FCME on the size of adipocytes in adipose tissues collected from epididymal, mesenteric, perirenal, and subcutaneous regions are shown in Figure 5. The sizes of adipocyte in HFD-fed mice were markedly increased as 


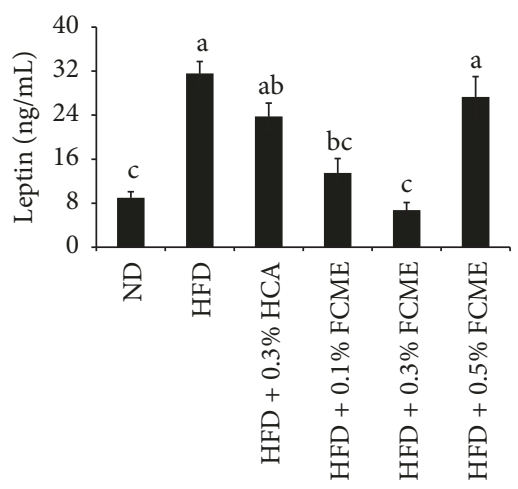

(a)

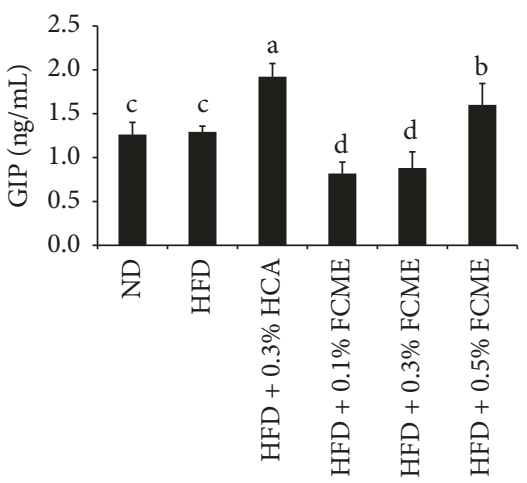

(d)

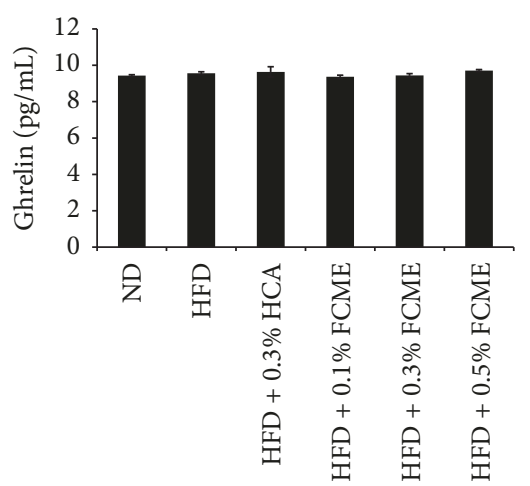

(b)

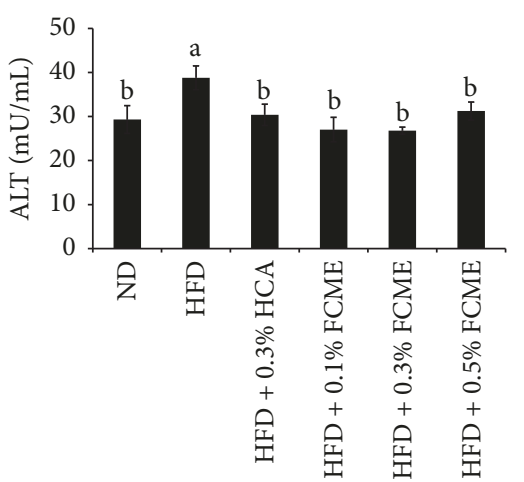

(e)

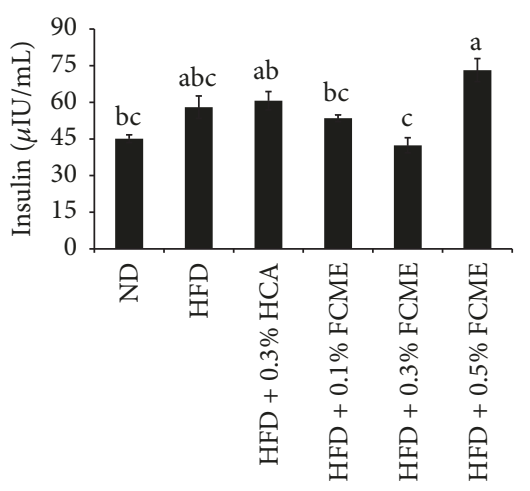

(c)

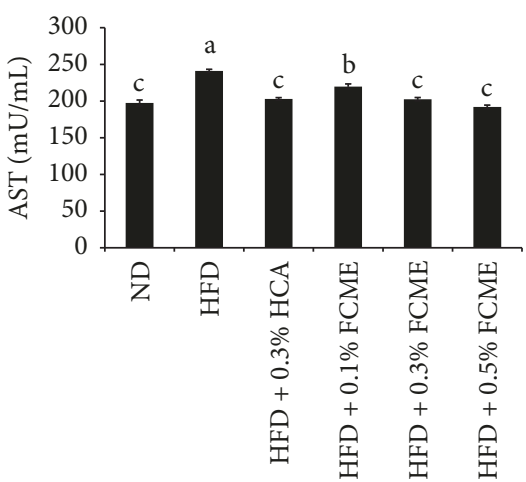

(f)

Figure 3: Effect of fermented Cucurbita moschata extract (FCME) on endocrine peptides and liver function enzymes of mice serum after 8 -week feeding of ND, and $0.1 \%, 0.3 \%$, and $0.5 \%$ of FCME-added high fat diet (HFD). (a) Leptin, (b) ghrelin, (c) insulin, (d) GIP, (e) ALT, and (f) AST. Different superscript letters are significantly different $(p<0.05)$ by ANOVA.

TABLE 2: Histological evaluation of liver of mice treated with fermented Cucurbita moschata extract.

\begin{tabular}{lccccc}
\hline Groups & Steatosis & Ballooning & Portal inflammation & Lobular activity & Fatty changes (lipidosis) \\
\hline ND & $0.67 \pm 0.58^{\mathrm{d}}$ & $0.00 \pm 0.00^{\mathrm{d}}$ & $0.00 \pm 0.00^{\mathrm{b}}$ & $0.00 \pm 0.00^{\mathrm{c}}$ & $0.33 \pm 0.58^{\mathrm{b}}$ \\
HFD & $4.67 \pm 0.58^{\mathrm{a}}$ & $4.00 \pm 1.00^{\mathrm{a}}$ & $3.33 \pm 1.15^{\mathrm{a}}$ & $2.67 \pm 1.53^{\mathrm{a}}$ & $5.00 \pm 0.00^{\mathrm{a}}$ \\
HFD + 0.3\% HCA & $2.00 \pm 0.00^{\mathrm{bc}}$ & $2.00 \pm 1.00^{\mathrm{b}}$ & $1.00 \pm 1.00^{\mathrm{b}}$ & $1.33 \pm 0.58^{\mathrm{abc}}$ & $0.67 \pm 0.58^{\mathrm{b}}$ \\
HFD + 0.1\% FCME & $2.67 \pm 0.58^{\mathrm{b}}$ & $1.67 \pm 0.58^{\mathrm{bc}}$ & $1.00 \pm 1.00^{\mathrm{b}}$ & $1.67 \pm 0.58^{\mathrm{ab}}$ & $1.00 \pm 1.00^{\mathrm{b}}$ \\
HFD + 0.3\% FCME & $1.00 \pm 1.00^{\mathrm{cd}}$ & $0.67 \pm 0.58^{\mathrm{cd}}$ & $0.33 \pm 0.58^{\mathrm{b}}$ & $0.67 \pm 0.58^{\mathrm{bc}}$ & $0.33 \pm 0.58^{\mathrm{b}}$ \\
HFD + 0.5\% FCME & $0.33 \pm 0.58^{\mathrm{d}}$ & $0.00 \pm 0.00^{\mathrm{d}}$ & $0.67 \pm 0.58^{\mathrm{b}}$ & $0.00 \pm 0.00^{\mathrm{bc}}$ & $0.67 \pm 0.58^{\mathrm{b}}$ \\
\hline
\end{tabular}

Duncan's multiple range test. 0: absent; 1: few; 2: mild; 3: moderate; 4: severe; and 5: extremely severe. ND: normal diet; HFD: high fat diet; HCA: hydroxycitric acid; FCME: fermented Cucurbita moschata extract; values not having the same superscript letter are significantly different $(p<0.05)$ by ANOVA.

compared to ND group. In contrast, feeding of FCMEsupplemented HFD reduced the size of adipocytes in aforementioned adipose tissues of mice.

3.5. Effects of FCME on Gene Expression. The mRNA expressions of PPAR $\gamma, \mathrm{C} / \mathrm{EBP} \alpha, \mathrm{C} / \mathrm{EBP}_{\beta}, \mathrm{C} / \mathrm{EBP} \gamma$, and SREBP-1C were significantly upregulated in HFD-fed mice compared to ND-fed mice (Table 3). However, these genes were markedly downregulated in mice fed with FCME-supplemented HFD. The mRNA expressions of ACC1, FAS, LPL, and GLUT4 were downregulated in livers of HFD-fed mice as compared to ND-fed mice. There were no significant differences in gene expression pattern of above genes when mice fed HFD supplemented with FCME as compared to ND group.
3.6. Acute Oral Toxicity. The application of FCME $(2000 \mathrm{mg} / \mathrm{kg}$ body weight) by oral route was safe. None of the animals showed behavioral manifestations of morbidity during the observation period. Furthermore, there were no remarkable differences in the body weight between control and treatment groups.

3.7. Compound Profile of FCME. The LC-MS and GC-MS analyses of FCME explored numerous types of compounds. The major identified compounds are listed in Table 4 with their reported biological activities. Mainly, surfactin derivatives are identified by LC-MS analysis, whereas pyrazine, tetramethyl, 2,3-butanediol, and some derivatives of 2,3butanediol were detected and identified by GC-MS analysis. 


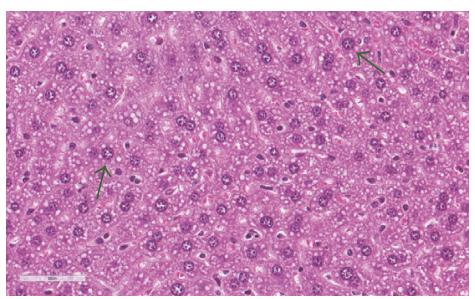

(a)

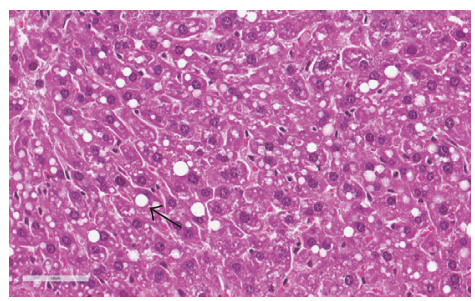

(d)

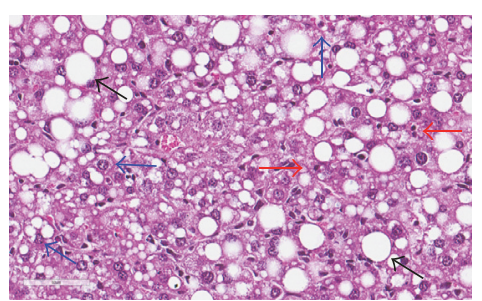

(b)

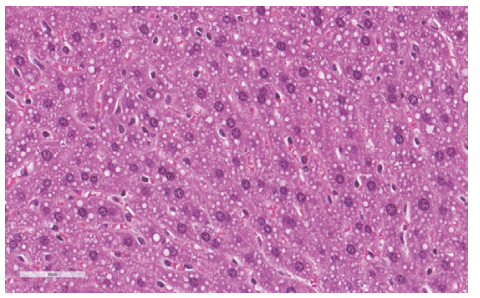

(e)

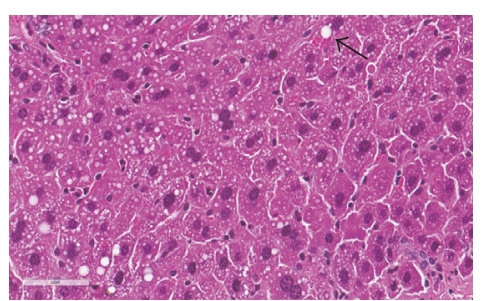

(c)

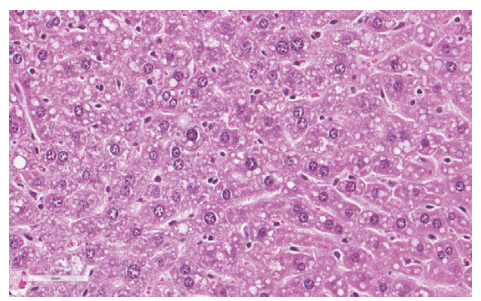

(f)

FIGURE 4: Haematoxylin and eosin staining of hepatic tissue (40x magnification). Mice fed normal diet (a); high fat diet (b); high fat diet with $0.3 \%$ HCA (c); high fat diet with 0.1\% FCME (d); high fat diet with 0.3\% FCME (e), and high fat diet with 0.5\% FCME (f). Well-structured hepatocytes are indicated by green arrows in (a). Blue arrows in (b) indicate hepatocyte lipid inclusion (steatosis) and ballooning. Red arrows in (b) indicate lobular activity. Black arrows in (b), (c), and (d) indicate fat droplets.

(A)

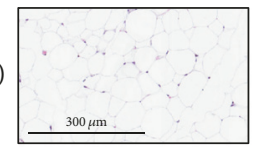

(B)

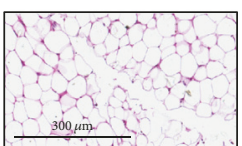

(C)

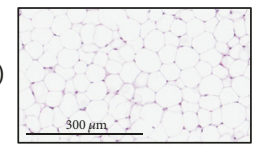

(D)

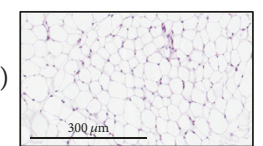

(a)
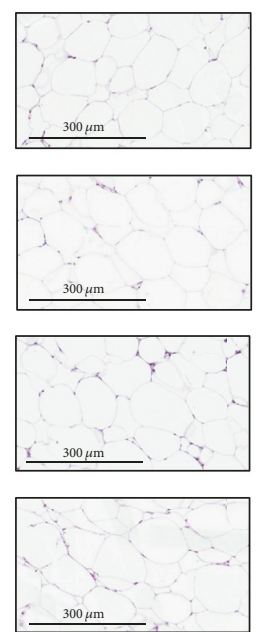

(b)
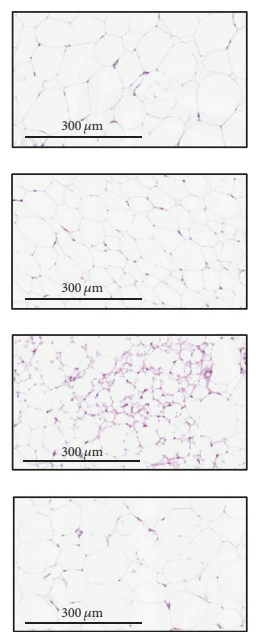

(c)
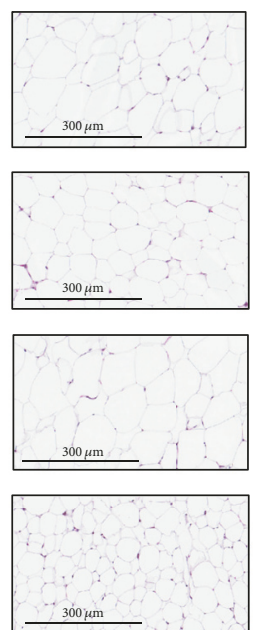

(d)
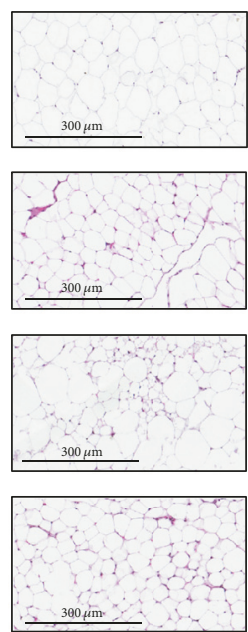

(e)
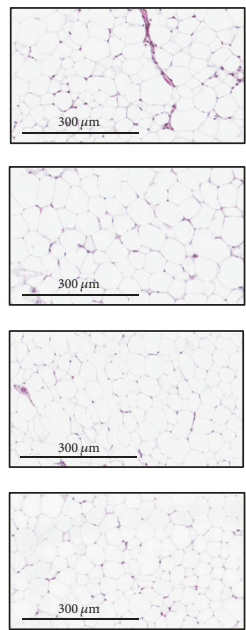

(f)

FIGURE 5: Haematoxylin and eosin staining of adipose tissues (10x magnification). In horizontal order, (A) epididymal, (B) mesenteric, (C) perirenal, and (D) subcutaneous adipose tissue. In vertical order, mice fed with (a) normal diet, (b) high fat diet, (c) high fat diet plus $0.3 \%$ HCA, (d) high fat diet plus 0.1\% FCME, (e) high fat diet plus 0.3\% FCME, and (f) high fat diet plus 0.5\% FCME.

\section{Discussion}

In this study, high fat diet-induced obesity model of mice was used which is considered as the most popular model among researchers because of its high similarity of mimicking the usual route of obesity episodes in human [17]. Moreover, feeding of HFD to animal can readily induce body weight gain and, hence, HFD-induced obesity model is considered as a reliable tool for studying obesity. A significant difference in the body weight gain was observed between HFD-fed mice and ND-fed mice, although the weekly food intake between these two groups of animals was not significantly different.
This observation makes it clearly evident that the increased body weight gain in HFD-fed mice is not associated with the amount of food consumption. The feeding of FCME (0.1-0.5\%) with HFD to animal reduced the body weight gain remarkably in comparison with the HFD only fed mice. This result suggests that the supplementation of $0.1 \%$ and $0.3 \%$ FCME can prevent the extra body weight gain, without inhibiting the general food consumption associated weight gain.

Obesity alters the endocrine and metabolic functions of adipose tissue and leads to increase in the release of hormones, fatty acids, and proinflammatory molecules that contribute to obesity associated complications [18]. Obesity can 
TABLE 3: Relative expressions of adipogenic and lipogenic genes of mice liver tissue after 8-week treatment with fermented Cucurbita moschata extract.

\begin{tabular}{lcccccc}
\hline Gene & ND & HFD & HFD $+0.3 \%$ HCA & HFD + 0.1\% FCME & HFD + 0.3\% FCME & HFD + 0.5\% FCME \\
\hline PPAR- $\gamma$ & $1.00 \pm 0.00^{\mathrm{bc}}$ & $1.62 \pm 0.14^{\mathrm{a}}$ & $1.21 \pm 0.09^{\mathrm{abc}}$ & $0.83 \pm 0.07^{\mathrm{c}}$ & $0.76 \pm 0.05^{\mathrm{c}}$ & $1.38 \pm 0.09^{\mathrm{ab}}$ \\
SREBP-1C & $1.00 \pm 0.00^{\mathrm{b}}$ & $1.77 \pm 0.02^{\mathrm{a}}$ & $1.18 \pm 0.03^{\mathrm{b}}$ & $1.08 \pm 0.10^{\mathrm{b}}$ & $1.07 \pm 0.09^{\mathrm{b}}$ & $1.04 \pm 0.13^{\mathrm{b}}$ \\
CEBP- $\alpha$ & $1.00 \pm 0.00^{\mathrm{b}}$ & $1.58 \pm 0.04^{\mathrm{a}}$ & $1.03 \pm 0.11^{\mathrm{b}}$ & $1.40 \pm 0.14^{\mathrm{ab}}$ & $1.32 \pm 0.08^{\mathrm{ab}}$ & $1.37 \pm 0.15^{\mathrm{ab}}$ \\
CEBP- $\beta$ & $1.00 \pm 0.00^{\mathrm{c}}$ & $1.76 \pm 0.06^{\mathrm{a}}$ & $1.39 \pm 0.05^{\mathrm{b}}$ & $1.03 \pm 0.13^{\mathrm{c}}$ & $1.29 \pm 0.06^{\mathrm{bc}}$ & $1.30 \pm 0.03^{\mathrm{bc}}$ \\
CEBP- $\gamma$ & $1.00 \pm 0.00^{\mathrm{a}}$ & $1.27 \pm 0.04^{\mathrm{a}}$ & $1.22 \pm 0.03^{\mathrm{a}}$ & $0.61 \pm 0.05^{\mathrm{b}}$ & $1.00 \pm 0.10^{\mathrm{a}}$ & $0.99 \pm 0.05^{\mathrm{a}}$ \\
ACC1 & $1.00 \pm 0.00$ & $1.06 \pm 0.06$ & $0.88 \pm 0.02$ & $0.93 \pm 0.01$ & $1.09 \pm 0.03$ & $1.01 \pm 0.04$ \\
FAS & $1.00 \pm 0.00$ & $1.18 \pm 0.06$ & $1.22 \pm 0.08$ & $1.34 \pm 0.12$ & $1.47 \pm 0.09$ & $1.32 \pm 0.19$ \\
GLUT4 & $1.00 \pm 0.00^{\mathrm{c}}$ & $0.39 \pm 0.01^{\mathrm{d}}$ & $1.07 \pm 0.03^{\mathrm{bc}}$ & $1.46 \pm 0.08^{\mathrm{ab}}$ & $0.94 \pm 0.04^{\mathrm{c}}$ & $1.53 \pm 0.09^{\mathrm{a}}$ \\
LPL & $1.00 \pm 0.00$ & $1.10 \pm 0.08$ & $0.94 \pm 0.09$ & $0.92 \pm 0.02$ & $0.84 \pm 0.06$ & $0.87 \pm 0.08$ \\
\hline
\end{tabular}

ND: normal diet; HFD: high fat diet; HCA: hydroxycitric acid; FCME: fermented Cucurbita moschata extract. PPAR- $\gamma$ : peroxisome proliferator-activated receptor- $\gamma$; C/EBP- $\alpha$ : CCAAT/enhancer binding protein- $\alpha$; C/EBP- $\beta$ : CCAAT/enhancer binding protein- $\beta$; C/EBP- $\gamma$ : CCAAT/enhancer binding protein- $\gamma$; FAS: fatty acid synthase; LPL: lipoprotein lipase; GLUT4: glucose transporter 4; SREBP-1C: sterol regulatory element-binding protein-1C; ACC1: acetyl-CoA carboxylase 1 ; values not having the same superscript letter are significantly different $(p<0.05)$ by ANOVA.

TABLE 4: List of compounds identified from fermented Cucurbita moschata extract by LC-MS and GC-MS analysis.

\begin{tabular}{|c|c|c|c|c|c|}
\hline \multicolumn{6}{|c|}{ LC-MS } \\
\hline $\begin{array}{l}\text { RT } \\
(\mathrm{min})\end{array}$ & $\begin{array}{l}\text { Name of } \\
\text { compound }\end{array}$ & $m / z\left([\mathrm{M}+\mathrm{H}]^{+}\right)$ & $\triangle \mathrm{ppm}$ & Pharmacological properties & References \\
\hline 24.74 & Surfactin C13 & 1022.6766 & 1.142 & $\begin{array}{l}\text { Antiviral, antimycoplasma, } \\
\text { antibacterial, } \\
\text { antihypercholesterolemia, } \\
\text { inflammation suppressor }\end{array}$ & [7] \\
\hline 25.17 & Surfactin C14 & 1036.36925 & 1.271 & $\begin{array}{l}\text { Antiviral, antimycoplasma, } \\
\text { antibacterial, } \\
\text { antihypercholesterolemia, } \\
\text { inflammation suppressor }\end{array}$ & [7] \\
\hline \multicolumn{6}{|c|}{ GC-MS } \\
\hline $\begin{array}{l}\text { RT } \\
(\mathrm{min})\end{array}$ & Name of & & $\begin{array}{c}\text { Area } \\
(\%)\end{array}$ & Pharmacological properties & References \\
\hline 4.26 & Cinnamy & nate & 6.53 & - & - \\
\hline 7.07 & $\mathrm{Am}$ & & 5.66 & - & - \\
\hline 23.64 & Acet & & 3.68 & - & - \\
\hline 24.01 & Pyrazine, & thyl & 1.13 & $\begin{array}{c}\text { Cardioprotective, } \\
\text { antihypertensive, } \\
\text { vasodilator, } \\
\text { anti-inflammatory, } \\
\text { anticoagulant, free } \\
\text { radical-scavenging }\end{array}$ & [8] \\
\hline 25.97 & $2,3-\mathrm{Bl}$ & & 45.86 & Psychoactive & [8] \\
\hline 39.66 & 2,3-Butaned & lamide & 26.90 & Effective against asthma & [9] \\
\hline 40.40 & Methyl p & her & 1.58 & - & - \\
\hline
\end{tabular}

be described as a state of excessive growth of adipose tissue mass. Thus, the adipose tissue mass of animal was recorded for comparative study. A significant induction in the weight of subcutaneous, mesenteric, perirenal, and epididymal adipose tissues was observed in HFD-fed mice compared to ND-fed mice, which were remarkably suppressed in HFD+FCMEfed mice (0.1-0.3\%) (Table 1$)$. Subcutaneous and visceral abdominal adipose tissues are major types of adipose tissues. Visceral fat is composed of several adipose depots, including epididymal, mesenteric, and perirenal adipose tissues.
Abdominal obesity is correlated with the increased risk of cardiovascular diseases and insulin resistance, whereas augmented subcutaneous fat is associated with a favorable plasma lipid profile [19]. Mesenteric adipose tissue is believed to play a central role in the development of obesity-related diseases [20]. Adiponectin and leptin are mainly available from subcutaneous adipocytes [19]. Certainly, the mean adipocyte mass of all types of adipose tissues was noticeably reduced in FCME-fed mice (Table 1). The major cellular component in adipose tissue is adipocyte; consequently, the 
mechanism that regulates the number and size of adipocyte has become a vital target in obesity research [21]. Excessive energy is stored as triglyceride in adipocytes and the expansion of adipocyte size (hypertrophy) means the elevation of intracellular lipid accumulation, which is dependent on the lipogenic activity of adipocyte [22]. The more influential aspect in the chronic situation of obesity is the increase in cell number (hyperplasia); however, the initial event of obesity development is hypertrophy [22].

Leptin and ghrelin are two hormones which are recognized to have major influence on energy balance. The adipocyte hormone that controls body weight by modulating food intake and energy expenditure is leptin [23]. The concentration of leptin is proportional to the percentage of body fat. Elevated levels of serum leptin were identified in obese people compared to nonobese people [24]. In the present study there was significant reduction in serum leptin in the HFD supplemented with $0.1 \%$ and $0.3 \%$ FCME as compared to HFD (Figure 3). This indicates that less body weight gain may be due to reduction of serum leptin [24]. Ghrelin controls the appetite and hunger by sending signal to brain that the subject is very hungry [25]. In this study, however; the levels of ghrelin were not significantly different among groups which indicate that the FCME does not influence the secretion and regulation of ghrelin.

In this study, apart from the reduction in body and adipose tissue weight, supplementation of FCME with HFD was observed to significantly attenuate the serum levels of total cholesterol (TC), free fatty acid (FFA), triglycerides (TG), atherogenic index (AI), and LDL. The basic mechanism behind the reduction in the level of TC, TG, FFA, LDL, and AI might be because of the breakdown of lipids by the components of the extract, thus modifying the altered lipid metabolism [26]. The reduction of TG, TC, LDL, and FFA in serum shows intensive clearance of circulating lipids. So reduction in lipoproteins and cholesterol levels further decreases complication and protects the cell from free radical induced damage [27]. Further, atherogenic index (AI) is considered as a marker for various cardiovascular disorders, and the AI value is directly proportional to the risk of developing cardiovascular disease and vice versa $[28,29]$. Thus, reduced AI values observed in the FCME-treated groups (0.1-0.5\%) are beneficial, because they possess lipid lowering properties with cardioprotective potential.

The ALT and AST have been the most commonly used parameters in laboratory testing for the evaluation of liver function, because these enzymes are cytoplasmic in location and are released into circulation after cellular damage [30]. The feeding of FCME- $(0.1 \%$ and $0.3 \%)$ supplemented HFD significantly inhibited the diet-induced elevation of ALT and AST (Figure 3). In addition, histopathological investigation also showed the protective effect of FCME from inflammation and steatosis, which further consolidates the serum biochemical assay findings.

The feeding of HFD to mice significantly increased the mRNA expressions of $\mathrm{PPAR}_{\gamma}, \mathrm{C} / \mathrm{EBP}_{\alpha}, \mathrm{C} / \mathrm{EBP}_{\beta}, \mathrm{C} / \mathrm{EBP}_{\gamma}$, and SREBP-1c genes compared to ND-fed mice. There were no significant differences observed in mRNA expressions in mice fed HFD supplemented with FCME as compared to ND.
In the past few decades, the role of $\mathrm{PPAR}_{\gamma}$ and SERBP-1c in the regulation of obesity and adipocyte differentiation has been highlighted and, hence, PPAR , agonists and antagonists of synthetic or herbal origin have gained wide commercial popularity as therapeutic agents [31]. Moreover, $\mathrm{PPAR}_{\gamma}$ regulates the expression of adipocyte genes such as adipocytefatty acid binding protein (A-FABP) [32]. SREBP-1c controls the expression of lipogenic genes such as ACC and FAS [33]. SREBP-1c also activates the $\mathrm{C} / \mathrm{EBP}_{\beta}$ promoter and insulinmediated transcriptional factors [24]. Significant upregulation of $\mathrm{PPAR}_{\gamma}, \mathrm{C} / \mathrm{EBP}_{\alpha}$, and SERBP-1c mRNA expressions in the present study is in accordance with the previous reports $[34,35]$. We observed tendencies for reduced SREBP-1c in the FCME-fed groups compared to the HFD group; however, we did not find any significant reduction in mRNA expression of FAS, the rate-limiting enzyme of fatty acid synthesis in the liver (Table 3). Moreover, LPL, which is related to fat intake, did not differ among the HFD only group and HFD-plusFCME-fed groups. Therefore, it shows that the antiobesity effect of FCME is responsible for the decreased expression of fatty acid metabolism-related genes rather than reduced fatty acid synthesis and fat intake in the liver.

The expression of another $\mathrm{PPAR}_{\gamma}$-mediated transcriptional factor, ACC1, was not changed. The expression and function of insulin-responsive GLUT4 are regulated by the $\mathrm{PPAR}_{\gamma}$ and free fatty acids [36]. The one of the main glucose transporters is GLUT4; it was reported that the changes in the expression of this gene were more related to type 2 diabetes and insulin resistance rather than obesity [37]. In this study, the GLUT4 mRNA expression in the liver tissue is increased significantly by FCME. Moreover, the level of insulin elevated in HFD group was significantly reduced by FCME supplementation (Figure 3) except for 0.5\% FCME. Hyperinsulinemia is considered as a biomarker of insulin resistance, and it is frequently accompanied by obesity [3]. It is expected that the antidiabetic activity of FCME can be attributed to the regulation of GLUT4 and insulin.

Probiotic Bacillus subtilis and lactic acid bacteria are reported in many recent studies for their preventive effect on obesity and metabolic syndrome [11, 13]. These probiotic bacteria produce 2,3-butanediol [38]. In this study, 2,3butanediol is identified and quantified as the major compound (about 73\%) of fermented FCME by GC-MS analysis. Our result is supported by the identification of lactate, acetate, and 2,3-butanediol in the growth medium as the major anaerobic fermentation products by using high-performance liquid chromatography [39]. Butanediol induces a reduction of cerebral glycolytic rate and affects the cerebral energy metabolism [40]. The cerebral energy metabolism has a very close relationship with systemic energy metabolism [41]. Surfactins, which are identified from the FCME by LC-MS/MS analysis, have been reported earlier for antidiabetic, antilipidemic, and antihypercholesterolemic properties [7, 13]. Thus, the antiobesity effect of FCME might be because of the presence of butanediol and surfactins in the extract.

In conclusion, the coadministration of FCME (0.1-0.3\%) with HFD restored the altered lipid profile and hepatic injury in the studied diet-induced obese mice model. The control of this extract on the regulation of these genes led to decreased 
lipid level, body weight, fat mass, adipocyte size, and hepatic abnormalities. This study is the first scientific report that provides convincing evidence for the relevance of fermented $C$. moschata as a food with antiobesity properties. These results suggest that the fermented C. moschata extract can be a promising candidate for the prevention of obesity.

\section{Conflicts of Interest}

All authors declare that there are no conflicts of interest in this study.

\section{Acknowledgments}

The study was supported in part by Korean Institute of Planning and Evaluation for Technology (IPET) through Technology Commercialization Support Program (3140823 ), the Ministry of Agriculture, Food and Rural Affairs, in part by the National Foundation of Korea (NRF) grant funded by the Korea government (2016R1A2B4013507), and in part by the Technology Development Program for Forestry (S111515L050130), Korea Forest Service, South Korea.

\section{Supplementary Materials}

Supplementary Table 1: compositions of experimental diet; the source of the feeds is Dyets Inc. (Bethlehem, PA, USA). Supplementary Table 2: base sequences of adipogenic and lipogenic primers. (Supplementary Materials)

\section{References}

[1] Y. Kang, H. Lee, J. Kim et al., "Anti-obesity and anti-diabetic effects of yerba mate," Laboratory Animal Research, vol. 28, no. 1, p. 23, 2012.

[2] E. Fabbrini, S. Sullivan, and S. Klein, "Obesity and nonalcoholic fatty liver disease: biochemical, metabolic, and clinical implications," Hepatology, vol. 51, no. 2, pp. 679-689, 2010.

[3] M. Liu, L. Xu, and L. Yin, "Potent effects of dioscin against obesity in mice," Scientific Reports, vol. 5, article 7973, 2015.

[4] C. J. Dillard and J. Bruce German, "Phytochemicals: nutraceuticals and human health," Journal of the Science of Food and Agriculture, vol. 80, no. 12, pp. 1744-1756, 2000.

[5] L.-M. Korou, G. Agrogiannis, A. Pantopoulou et al., "Comparative antilipidemic effect of $\mathrm{N}$-acetylcysteine and sesame oil administration in diet-induced hypercholesterolemic mice," Lipids in Health and Disease, vol. 9, article no. 23, 2010.

[6] X. Yang, Y. Zhao, and Y. Lv, "Chemical composition and antioxidant activity of an acidic polysaccharide extracted from Cucurbita moschata duchesne ex poiret," Journal of Agricultural and Food Chemistry, vol. 55, no. 12, pp. 4684-4690, 2007.

[7] M. Deleu, J. Lorent, L. Lins et al., "Effects of surfactin on membrane models displaying lipid phase separation," Biochimica et Biophysica Acta (BBA) - Biomembranes, vol. 1828, no. 2, pp. 801815, 2013.

[8] M. Guo, Y. Liu, and D. Shi, "Cardiovascular actions and therapeutic potential of tetramethyl pyrazine (active component isolated from rhizoma chuanxiong): roles and mechanisms," BioMed Research International, vol. 2016, Article ID 2430329, 9 pages, 2016.
[9] G. D. Frye, R. E. Chapin, R. A. Vogel et al., "Effects of acute and chronic 1, 3-butanediol treatment on central nervous system function: a comparison with ethanol," The Journal of Pharmacology and Experimental Therapeutics, vol. 216, no. 2, pp. 306314, 1981.

[10] F. Caili, S. Huan, and L. Quanhong, "A review on pharmacological activities and utilization technologies of pumpkin," Plant Foods for Human Nutrition, vol. 61, no. 2, pp. 73-80, 2006.

[11] M. Kumar, R. Nagpal, R. Kumar et al., "Cholesterol-lowering probiotics as potential biotherapeutics for metabolic diseases," Journal of Diabetes Research, vol. 2012, Article ID 902917, 14 pages, 2012.

[12] R. Salaj, J. Štofilová, A. Šoltesová et al., “The effects of two lactobacillus plantarum strains on rat lipid metabolism receiving a high fat diet," The Scientific World Journal, vol. 2013, Article ID 135142, 7 pages, 2013.

[13] R. Zouari, R. Ben Abdallah-Kolsi, K. Hamden et al., "Assessment of the antidiabetic and antilipidemic properties of bacillus subtilis spbl biosurfactant in alloxan-induced diabetic rats," Biopolymers, vol. 104, no. 6, pp. 764-774, 2015.

[14] H. Nam, H. Jung, S. Karuppasamy et al., "Anti-diabetic effect of the soybean extract fermented by bacillus subtilis MORI in db/db mice," Food Science and Biotechnology, vol. 21, no. 6, pp. 1669-1676, 2012.

[15] M. A. Reza, M. A. Hossain, D. Damte, W.-S. Jo, W. H. Hsu, and S.-C. Park, "Hypolipidemic and hepatic steatosis preventing activities of the wood ear medicinal mushroom auricularia auricula-judae (Higher basidiomycetes) ethanol extract in vivo and in vitro," International Journal of Medicinal Mushrooms, vol. 17, no. 8, pp. 723-734, 2015.

[16] M. A. Hossain, S.-J. Lee, J.-Y. Park et al., "Modulation of quorum sensing-controlled virulence factors by nymphaea tetragona (water lily) extract," Journal of Ethnopharmacology, vol. 174, article no. 9714, pp. 482-491, 2015.

[17] R. Buettner, J. Schölmerich, and L. C. Bollheimer, "High-fat diets: modeling the metabolic disorders of human obesity in rodents," Obesity, vol. 15, no. 4, pp. 798-808, 2007.

[18] S. P. Weisberg, D. McCann, M. Desai, M. Rosenbaum, R. L. Leibel, and A. W. Ferrante Jr., "Obesity is associated with macrophage accumulation in adipose tissue," The Journal of Clinical Investigation, vol. 112, no. 12, pp. 1796-1808, 2003.

[19] A. Wronska and Z. Kmiec, "Structural and biochemical characteristics of various white adipose tissue depots," Acta Physiologica, vol. 205, no. 2, pp. 194-208, 2012.

[20] Y.-K. Yang, M. Chen, R. H. Clements, G. A. Abrams, C. J. Aprahamian, and C. M. Harmon, "Human mesenteric adipose tissue plays unique role versus subcutaneous and omental fat in obesity related diabetes," Cellular Physiology and Biochemistry, vol. 22, no. 5-6, pp. 531-538, 2008.

[21] P. A. Heine, J. A. Taylor, G. A. Iwamoto, D. B. Lubahn, and P. S. Cooke, "Increased adipose tissue in male and female estrogen receptor- $\alpha$ knockout mice," Proceedings of the National Acadamy of Sciences of the United States of America, vol. 97, no. 23, pp. 12729-12734, 2000.

[22] K. Liu, Y. Guan, M. C. MacNicol, A. M. MacNicol, and R. E. McGehee Jr., "Early expression of p107 is associated with 3T3-L1 adipocyte differentiation," Molecular and Cellular Endocrinology, vol. 194, no. 1-2, pp. 51-61, 2002.

[23] E. Jéquier, "Leptin signaling, adiposity, and energy balance," Annals of the New York Academy of Sciences, vol. 967, pp. 379$388,2002$. 
[24] R. V. Considine, M. K. Sinha, M. L. Heiman et al., "Serum immunoreactive-leptin concentrations in normal-weight and obese humans," The New England Journal of Medicine, vol. 334, no. 5, pp. 292-295, 1996.

[25] R. S. Ahima and D. A. Antwi, "Brain regulation of appetite and satiety," Endocrinology and Metabolism Clinics of North America, vol. 37, no. 4, pp. 811-823, 2008.

[26] C. Juhel, M. Armand, Y. Pafumi, C. Rosier, J. Vandermander, and D. Lairon, "Green tea extract (AR25 ${ }^{\circledR}$ ) inhibits lipolysis of triglycerides in gastric and duodenal medium in vitro," The Journal of Nutritional Biochemistry, vol. 11, no. 1, pp. 45-51, 2000.

[27] M. C. Sabu and R. Kuttan, "Antidiabetic activity of aegle marmelos and its relationship with its antioxidant properties," Indian Journal of Physiology and Pharmacology, vol. 48, no. 1, pp. 81-88, 2004.

[28] J. C. Ikewuchi, E. N. Onyeike, A. A. Uwakwe, and C. C. Ikewuchi, "Effect of aqueous extract of the leaves of Acalypha wilkesiana "Godseffiana" Muell Arg (Euphorbiaceae) on the hematology, plasma biochemistry and ocular indices of oxidative stress in alloxan induced diabetic rats," Journal of Ethnopharmacology, vol. 137, no. 3, pp. 1415-1424, 2011.

[29] Z. Altunkaynak, "Effects of high fat diet induced obesity on female rat livers (a histochemical study)," European Journal of General Medicine, vol. 2, no. 3, pp. 100-109, 2005.

[30] R. O. Recknagel, J. A. Glende, and R. S. Britton, "Free radical damage and lipid peroxidation," in Hepatotoxicology, RG. Meeks, Ed., pp. 401-436, CRC Press, Fla, USA, 1991.

[31] R. N. Jadeja, M. C. Thounaojam, U. V. Ramani, R. V. Devkar, and A. V. Ramachandran, "Anti-obesity potential of clerodendron glandulosum.Coleb leaf aqueous extract," Journal of Ethnopharmacology, vol. 135, no. 2, pp. 338-343, 2011.

[32] M. Furuhashi and G. S. Hotamisligil, "Fatty acid-binding proteins: role in metabolic diseases and potential as drug targets," Nature Reviews Drug Discovery, vol. 7, no. 6, pp. 489-503, 2008.

[33] H. Guillou, P. G. P. Martin, and T. Pineau, "Transcriptional regulation of hepatic fatty acid metabolism," Subcellular Biochemistry, vol. 49, pp. 3-47, 2008.

[34] T. Watanabe, K. Hata, K. Hiwatashi, K. Hori, N. Suzuki, and H. Itoh, "Suppression of murine preadipocyte differentiation and reduction of visceral fat accumulation by a petasites japonicus ethanol extract in mice fed a high-fat diet," Bioscience, Biotechnology, and Biochemistry, vol. 74, no. 3, pp. 499-503, 2010.

[35] Y.-Y. Sung, T. Yoon, S. J. Kim, W.-K. Yang, and H. K. Kim, "Antiobesity activity of allium fistulosum L. extract by down-regulation of the expression of lipogenic genes in high-fat dietinduced obese mice," Molecular Medicine Reports, vol. 4, no. 3, pp. 431-435, 2011.

[36] M. Armoni, C. Harel, and E. Karnieli, "Transcriptional regulation of the GLUT4 gene: from PPAR- $\gamma$ and FOXO1 to FFA and inflammation," Trends in Endocrinology \& Metabolism, vol. 18, no. 3, pp. 100-107, 2007.

[37] S. Kouidhi, R. Berrhouma, K. Rouissi et al., "Human subcutaneous adipose tissue Glut 4 mRNA expression in obesity and type 2 diabetes," Acta Diabetologica, vol. 50, no. 2, pp. 227-232, 2013.

[38] H.-S. Yi, Y.-R. Ahn, G. C. Song et al., "Impact of a bacterial volatile 2,3-butanediol on Bacillus subtilis rhizosphere robustness," Frontiers in Microbiology, vol. 7, article no. 993, 2016.

[39] H. C. Ramos, T. Hoffmann, M. Marino et al., "Fermentative metabolism of bacillus subtilis: physiology and regulation of gene expression," Journal of Bacteriology, vol. 182, no. 11, pp. 3072-3080, 2000.
[40] S. Gueldry and J. Bralet, "Effect of 1,3-butanediol on cerebral energy metabolism. Comparison with $\beta$-hydroxybutyrate," Metabolic Brain Disease, vol. 9, no. 2, pp. 171-181, 1994.

[41] B. Göbel, K. M. Oltmanns, and M. Chung, "Linking neuronal brain activity to the glucose metabolism," Theoretical Biology and Medical Modelling, vol. 10, no. 1, article no. 50, 2013. 


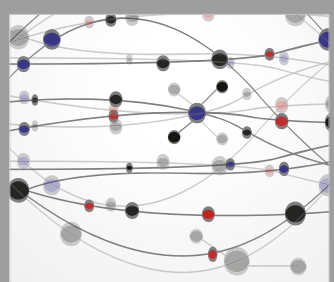

The Scientific World Journal
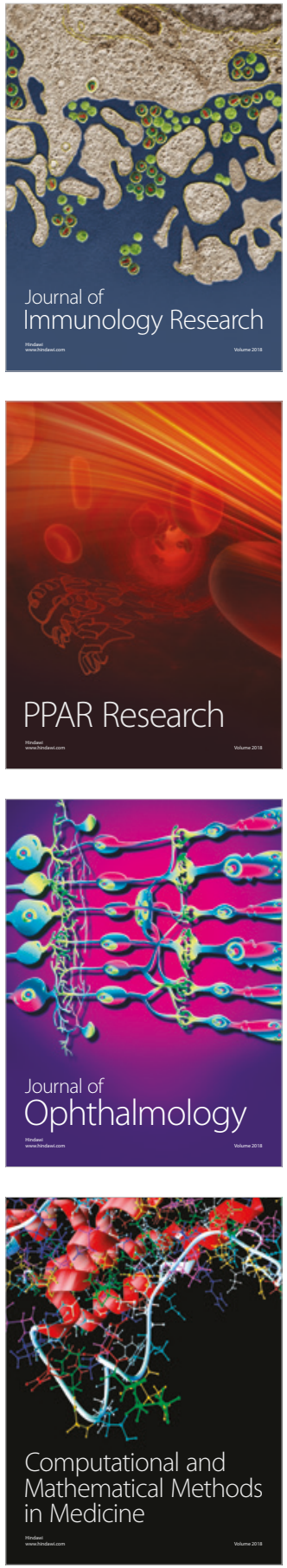

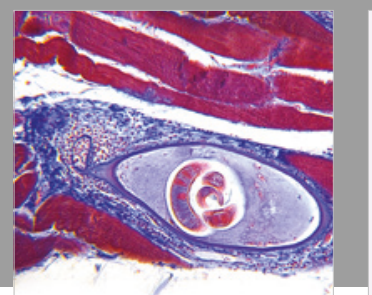

Gastroenterology Research and Practice

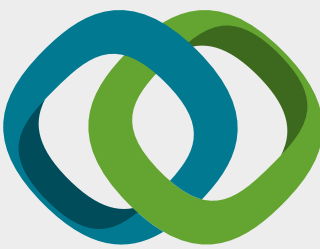

\section{Hindawi}

Submit your manuscripts at

www.hindawi.com
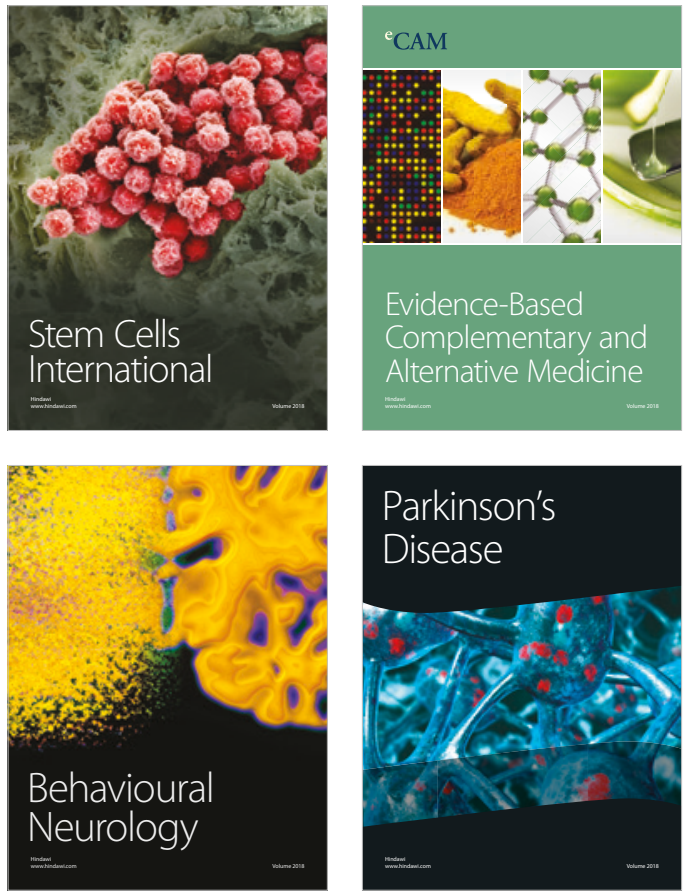

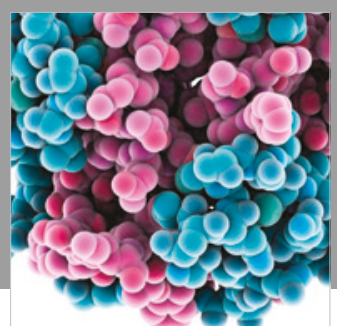

ournal of

Diabetes Research

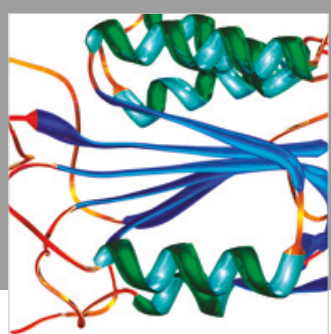

Disease Markers
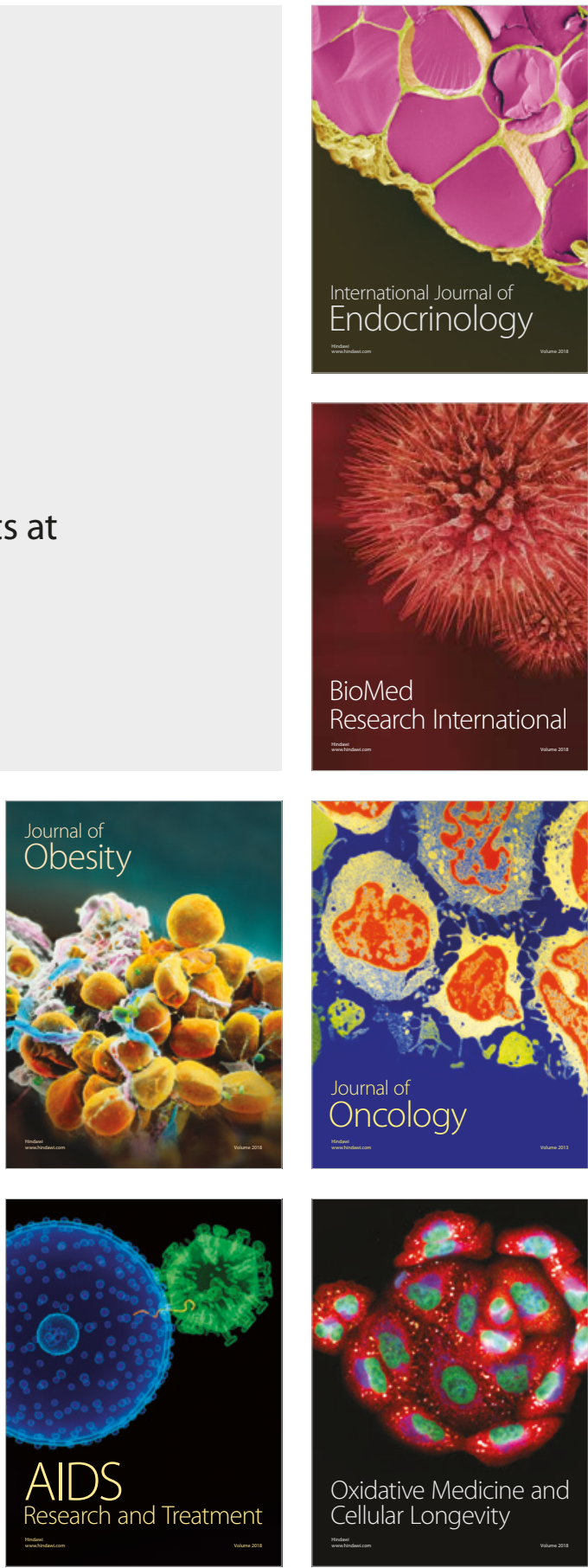